\title{
Efficacy of Fungicides and Bioagents against Early Blight of Tomato caused by Alternaria solani
}

\author{
N. S. Pondkule, V. M. Gholve* and S. V. Pawar \\ Department of Plant Pathology, College of Agriculture Vasantrai Naik Agricultural, \\ University, Parbhani (Maharashtra), India \\ *Corresponding author
}

\section{A B S T R A C T}

\section{Keywords \\ Tomato, Lycopersicon esculentum, Fungicides, Bioagents, Efficacy \\ Article Info \\ Accepted: 17 October 2020 Available Online: 10 November 2020}

Tomato (Lycopersicon esculentum Mill.), is one of the most popular fruit vegetable crop grown throughout the world. However, during recent years the crop has severely been affected by the early blight of tomato (Alternaria solani), causing about 48-80 per cent fruit yield losses. Though, the disease can be managed with various conventional fungicides and bio-agents under laboratory condition but new generation chemical molecules needs to be assessed for their efficacy against the disease. Three Systemic fungicides (@1000 ppm), four non-systemic fungicides (1500 ppm) and three combi (1500 ppm) fungicides were evaluated. Similarly six fungal antagonists and two bacterial antagonist were evaluated against $M$. phaseolina by poison food technique and duel culture method respectively. Per cent Inhibition was ranged from 50.81 to 94.44 and bioagent tested per cent inhibition ranged from 44.14 to 74.92 .

\section{Introduction}

Tomato (Lycopersicon esculentum Mill.), is one of the most popular fruit vegetable crop grown throughout the world. It is considered as "Protective Food", because of its special nutritive values and its wide spread cultivation. It is the most remunerative vegetable crop, which ranks next to potato in world acreage and ranks first among the processing crops.

Tomato is native of Central and South America from where it has spread to other parts of the world in sixteenth century. It was introduced in India by the Portuguese during 1700 (Kale and Kale, 1994).

In India's total production of 19696.9 thousand tones from an area of 808.5 thousand hectares with an average productivity of 24.40 tones ha-1 during 201617 (Anonymous, 2017) In Maharashtra area under tomato cultivation was 43.64 thousand hectares with production of 957.17 metric tonnes productivity of 21.93 metric tonnes per hectares during 2016-2017 (Anonymous, 2017) fiber $(0.7 \mathrm{~g})$ per $100 \mathrm{~g}$ of edible portion. 
Among the biotic causes, fungi are most important which cause the major diseases viz., damping off (Pythium aphanidermatum), Late blight (Phytophthora infestans), Fruit rot (Alternaria alternata), Early blight (Alternaria solani), Fusarium wilt (Fusarium oxysporium f. sp. lycopersici) and Powdery mildew (Leveillula taurica).

The important bacterial diseases include, bacterial wilt (Ralstonia solanacearum), bacterial canker (Clavibacter michiganense subsp. michiganense), bacterial leaf spot (Xanthomonas campestris pv. vesicatoria), nematode diseases like root knot nematode caused by Meloidogyne spp. and viral diseases like tomato leaf curl, tomato spotted wilt virus and tomato mosaic.

Among the fungal diseases infecting tomato crop, early blight caused by Alternaria solani (Ellis and Martin) Jones and Grout, is one of the most destructive disease causing accountable qualitative and quantitative losses. The causal organism is air borne and soil inhabiting and responsible for early blight, It also infects fruits causing shedding of immature fruits up to 30 per cent (Walker, 1951).

The disease is most severe in Kharif but it also appears throughout the year affecting the yield and quality of fruits (Wilson 1943, Basu, 1973 and Gleason et al., 1993).

The yield losses in the range of 48-80 per cent due to early blight (Alternaria solani) damage in tomato were reported from India, Canada, USA and Nigeria (Basu, 1974; Datar and Mayee, 1984; Mathur and Shekhawat, 1986; Sherf and MacNab, 1986; Gwary and Nahunnarao, 1998 and Pandey and Pandey, 2002). The annual economic yield losses due to early blight have been estimated at $79 \%$ (Adhikari and Panthee, 2017).

\section{Materials and Methods}

\section{In vitro evaluation of fungicides}

Efficacy of three systemic fungicide viz., Azoxystrobin 23\%EC, Pyraclostrobin 20\% WG, Propiconazole 25EC, and Four Non systemic fungicides viz., Mancozeb $75 \mathrm{WP}$, Copper oxychloride $50 \mathrm{WP}$, Captan 50\% WP, Propineb $70 \mathrm{WP}$, and three combi fungicide viz Azoxystrobin18.2 w/w+ Difenoconazole $11.4 \%$ w/w (Amister Top), Tebuconazole 50 $\%+$ Trifloxystrobin $25 \%$ WG(Nativo), Mancozeb + Metalaxyl (Redomil - MZ $72 \%$ WP) were evaluated at different concentrations (systemic each @ 1000 and Non systemic \& combi each @ 1500) in vitro against A. solani (PBN-3 isolate) applying Poisoned Food Technique (Nene and Thapliyal, 1993) and using Potato dextrose agar (PDA) as basal culture medium. Based on active ingredient, requisite quantity of each test fungicide was calculated and mixed thoroughly with autoclaved and cooled $\left(40^{\circ} \mathrm{C}\right)$ PDA medium in conical flasks to obtain desired concentrations of the test fungicides. Fungicide amended PDA medium was then poured aseptically in Petri plates $(90 \mathrm{~mm}$ dia.) and allowed to solidify at room temperature. For each of the test fungicide and its desired concentrations, three plates / treatment / replication were maintained. After solidification of the medium, all the plates were inoculated aseptically with $5 \mathrm{~mm}$ culture disc obtained from a week old actively growing pure culture of $A$. solani.

The disc was placed on PDA in the centre of the Petri plate and plates were incubated in inverted position at $26 \pm 2^{0} \mathrm{C}$. Each of the test fungicide and its concentration were replicated thrice. Petri plates filled with plain PDA (without fungicide) and inoculated with the culture disc of $A$. solani were maintained as unpoisoned control. 


\section{Experimental details}

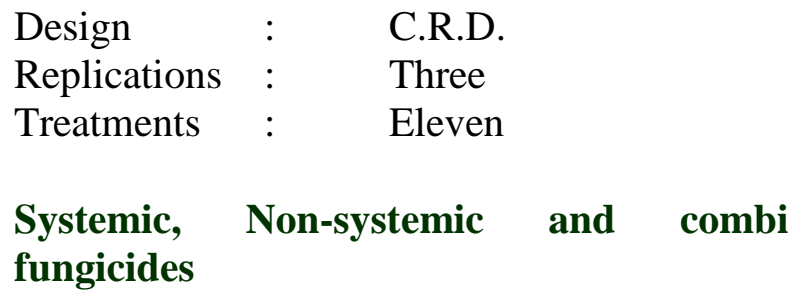

\begin{tabular}{|c|c|}
\hline $\begin{array}{l}\text { Treatment } \\
\text { No. }\end{array}$ & Treatments \\
\hline \multicolumn{2}{|c|}{ Systemic fungicides@1000ppm } \\
\hline $\mathbf{T}_{1}$ & Azoxystrobin $23 \% \mathrm{SC}$ \\
\hline $\mathbf{T}_{2}$ & Pyraclostrobin $20 \% \mathrm{WG}$ \\
\hline $\mathbf{T}_{3}$ & Propiconazole $25 \%$ EC \\
\hline \multicolumn{2}{|c|}{ Non-systemic fungicides @1500ppm } \\
\hline $\mathbf{T}_{4}$ & Copper oxychloride $50 \% \mathrm{WP}$ \\
\hline $\mathbf{T}_{5}$ & Captan 50\%WP \\
\hline $\mathbf{T}_{6}$ & Mancozeb $75 \%$ WP \\
\hline $\mathbf{T}_{7}$ & Propineb $70 \% \mathrm{WP}$ \\
\hline \multicolumn{2}{|c|}{ Combi fungicides@1500ppm } \\
\hline$T_{8}$ & $\begin{array}{c}\text { Azoxystrobin } 18.2 \% \mathrm{~W} / \mathrm{W}+ \\
\text { Difenoconazole } 11.4 \% \mathrm{~W} / \mathrm{W}\end{array}$ \\
\hline $\mathbf{T}_{\mathbf{9}}$ & $\begin{array}{c}\text { Tebuconazole } 50 \%+\text { Trifloxystrobin } \\
25 \% \text { WG }\end{array}$ \\
\hline $\mathbf{T}_{10}$ & $\begin{array}{c}\text { Mancozeb } 64 \% \text { w/w + Metalaxyl } \\
4 \% \text { w/w }\end{array}$ \\
\hline $\mathbf{T}_{11}$ & Control \\
\hline
\end{tabular}

Observations on radial mycelial growth/ colony diameter were recorded at an interval of 24 hours and continued till untreated control plates were fully covered with mycelial growth of the test fungus. Per cent inhibition of the test fungus with the test fungicides over untreated control was calculated by applying following formula (Vincent, 1927).

$$
\mathrm{C}-\mathrm{T}
$$

Per cent inhibition= - ---------------- x 100

Where,

$\mathrm{C}=$ growth of the test fungus in untreated control plates

$\mathrm{T}=$ growth of the test fungus in treated plates

\section{In vitro evaluation of bioagents}

Six fungal antagonists viz., Trichoderma viride, $T$. harzianum, $T$. hamatum, $T$. longibrachiatum, T. koningii, Glocladium virens, and two bacterial antagonist Pseudomonas fluorescens \& Bacillus subtilis were evaluated in vitro against $A$. solani (PBN3 isolate), applying Dual Culture Technique (Dennis and Webster, 1971). Seven days old cultures of the test bioagents and test fungus (A. solani) grown on (PDA) were used for the study. Discs (5 mm dia) of PDA along with culture growth of the test fungus and bioagents were cut out with sterilized cork borer. Then two culture discs, one each of the test fungus and bioagent were placed at equidistance and exactly opposite with each other on solidified PDA medium in Petri plates aseptically and plates were incubated at $26 \pm 2^{0} \mathrm{C}$. PDA plates inoculated only with culture disc of the test fungus were maintained as untreated control.

\section{Experimental details}

$\begin{array}{lll}\text { Design } & : & \text { CRD } \\ \text { Replications } & : & \text { Three } \\ \text { Treatments } & : & \text { Nine } \\ \mathrm{T}_{1} & : & \text { T. viride } \\ \mathrm{T}_{2} & : & \text { T. harzianum } \\ \mathrm{T}_{3} & : & \text { T. hamatum } \\ \mathrm{T}_{4} & : & \text { T. longibrachiatum } \\ \mathrm{T}_{5} & : & \text { T. koningii } \\ \mathrm{T}_{6} & : & \text { Gliocladium virens } \\ \mathrm{T}_{7} & : & \text { Bacillus subtilis } \\ \mathrm{T}_{8} & : & \text { P. fluorescens } \\ \mathrm{T}_{9} & : & \text { Control (untreated) }\end{array}$

Observations on linear mycelial growth of the test fungus and bioagent were recorded at an interval of 24 hours and continued till untreated control plates were fully covered with mycelial growth of the test fungus. Per cent inhibition of the test fungus by the bioagents over untreated control was 
calculated by applying following formula (Arora and Upaddhyay, 1978).



The data obtained in all the experiments were statistically analyzed (Panse and Sukhatme, 1978). The percentage values were transformed into arcsine values. The standard error (SE) and critical difference (C.D.) at level $\mathrm{P}=0.05$ were worked out and results obtained were compared statistically. All the statistical analysis was done using MAUSTAT statistical programme at Central Computer Laboratory, VNMKV, Parbhani.

\section{Results and Discussion}

In vitro efficacy of fungicides on growth of Alternaria solani

\section{Mycelial growth inhibition}

Results (Table 1 and PLATE- I) revealed that all the 11 fungicides tested (@1000, 1500 PPM) significantly inhibited mycelial growth of A solani over untreated control $(00.00 \%)$. Further, the percentage mycelial growth inhibition increased with increase in concentrations of the fungicides tested.

At $1000 \mathrm{ppm}$, systemic fungicides (Table 1 and PLATE- I) mycelial growth inhibition of the test pathogen ranged from $56.88 \%$ (Pyraclostrobin 20\%WG) to 94.44 per cent (Propiconazole 25\% EC). However, fungicide Propiconazole was found best, inhibited (94.44\%) mycelial growth. The second and third best fungicides found were $56.88 \%$ (Pyraclostrobin 20\%WG) and Azoxystrobin $23 \%$ SC (66.24\%)

At 1500 ppm Non-systemic) (Table 1 and PLATE- I) mycelial growth inhibition was ranged from $50.81 \%$ (Copper oxychloride) to $94.44 \%$ (Propineb). The second best fungicide was found Captan $(66.10 \%)$ followed by the fungicide Mancozeb $(62.77 \%)$.

At 1500 ppm Combi fungicides (Table 1 and PLATE- I) tested mycelial growth inhibition was ranged from 64.23 (Mancozeb + Metalaxyl) to $94.44 \%$ (Azoxystrobin + Difenoconazole)and (Tebuconazole + Trifloxystrobin).

Thus, all the fungicides tested were found fungistatic against $A$ solani and significantly inhibited its mycelial growth over untreated control.

Similar fungistatic effects of the test fungicides against $A$ solani infecting tomato and many other crops were reported earlier by several workers.

Rajani and Rakholia (2012) studied management of fruit rot of chilli caused by $A$. alternata with systemic and non-systemic fungicides in vitro as well as in vivo conditions. Systemic fungicide Hexaconazole gave cent per cent inhibition, followed by Tridemorph (93.65\%) and Propiconzaole (91.42\%), whereas in non-systemic fungicides Mancozeb and Zineb gave cent per cent inhibition of A. alternata.

Kumar et al., (2017) were carried out similar in vitro managment of early blight of tomato in year 2015-2016. Among the fungicides tested most effective was score with mycelium inhibition growth upto 78.61 percent followed by carbendazim (76.67per cent).

\section{In vitro evaluation of bioagents}

The results obtained on mycelial growth and inhibition of $A$. solani with six fungal and two 
bacterial antagonists are presented in (Table 2 and PLATE II). Results revealed that all the bioagents evaluated exhibited fungistatic / antifungal activity against A.solani and significantly inhibited its growth over untreated control.

Table.1 In vitro efficacy of Systemic, Non-systemic \& Combi fungicides against A. solani

\begin{tabular}{|c|c|c|c|}
\hline Treatment & Treatments & $\begin{array}{l}\text { *Average Colony } \\
\text { Dia. }(\mathbf{m m})\end{array}$ & $\begin{array}{c}\text { \#A verage\% } \\
\text { Inhibition over } \\
\text { control }\end{array}$ \\
\hline \multicolumn{4}{|c|}{ Systemic fungicides@1000ppm } \\
\hline $\mathbf{T}_{1}$ & Azoxystrobin $23 \% \mathrm{SC}$ & $\begin{array}{c}30.38 \\
(17.68)\end{array}$ & $\begin{array}{c}66.24 \\
(41.47)\end{array}$ \\
\hline $\mathbf{T}_{2}$ & Pyraclostrobin $20 \% \mathrm{WG}$ & $\begin{array}{l}38.90 \\
(22.88)\end{array}$ & $\begin{array}{c}56.88 \\
(34.67)\end{array}$ \\
\hline $\mathbf{T}_{3}$ & Propiconazole 25\% EC & $\begin{array}{c}5.0 \\
(28.65)\end{array}$ & $\begin{array}{c}94.44 \\
(70.79)\end{array}$ \\
\hline \multicolumn{4}{|c|}{ Non-systemic fungicides @1500ppm } \\
\hline $\mathbf{T}_{4}$ & Copper oxychloride $50 \% \mathrm{WP}$ & $\begin{array}{l}42.26 \\
(26.27)\end{array}$ & $\begin{array}{c}50.81 \\
(29.75)\end{array}$ \\
\hline $\mathbf{T}_{5}$ & Captan 50\%WP & $\begin{array}{c}30.43 \\
(17.75)\end{array}$ & $\begin{array}{c}66.10 \\
(40.32)\end{array}$ \\
\hline $\mathbf{T}_{6}$ & Mancozeb $75 \% \mathrm{WP}$ & $\begin{array}{c}33.5 \\
(19.57)\end{array}$ & $\begin{array}{c}62.77 \\
(38.90)\end{array}$ \\
\hline $\mathbf{T}_{7}$ & Propineb $70 \% \mathrm{WP}$ & $\begin{array}{c}5.0 \\
(28.65)\end{array}$ & $\begin{array}{c}94.44 \\
(70.79)\end{array}$ \\
\hline \multicolumn{4}{|c|}{ Combi fungicides@1500ppm } \\
\hline $\mathbf{T}_{8}$ & $\begin{array}{l}\text { Azoxystrobin } 18.2 \% \mathrm{~W} / \mathrm{W}+ \\
\text { Difenoconazole } 11.4 \% \mathrm{~W} / \mathrm{W}\end{array}$ & $\begin{array}{c}5.0 \\
(28.65)\end{array}$ & $\begin{array}{c}94.44 \\
(70.79)\end{array}$ \\
\hline $\mathbf{T}_{9}$ & $\begin{array}{c}\text { Tebuconazole } 50 \%+\text { Trifloxystrobin } \\
25 \% \mathrm{WG}\end{array}$ & $\begin{array}{c}5.0 \\
(28.65)\end{array}$ & $\begin{array}{c}94.44 \\
(70.79)\end{array}$ \\
\hline $\mathbf{T}_{10}$ & $\begin{array}{l}\text { Mancozeb 64\%w/w + } \\
\text { Metalaxyl 4\%w/w }\end{array}$ & $\begin{array}{c}32.26 \\
(18.82)\end{array}$ & $\begin{array}{c}64.23 \\
(39.97)\end{array}$ \\
\hline $\mathbf{T}_{11}$ & Control & $\begin{array}{l}90.00 \\
(64.15)\end{array}$ & 00.00 \\
\hline \multicolumn{2}{|l|}{ SE \pm} & 0.67 & 0.70 \\
\hline \multicolumn{2}{|l|}{$\mathrm{CD}(\mathbf{P}=\mathbf{0 . 0 5})$} & 1.97 & 2.07 \\
\hline
\end{tabular}

*Mean of three replications, Dia.=Diameter, \#Figures in parenthesis are arc sine transformed value 
Table.2 In vitro efficacy of bioagents against $A$. solani

\begin{tabular}{|c|c|c|}
\hline Treatments & $\begin{array}{l}\text { *Average Colony Dia. } \\
\text { of test pathogen }(\mathrm{mm})\end{array}$ & $\begin{array}{c}{ }^{\#} \text { Average \% } \\
\text { Inhibition } \\
\text { over control }\end{array}$ \\
\hline Trichoderma viride & 22.50 & $\begin{array}{c}74.92 \\
(48.55)\end{array}$ \\
\hline T. harzianum & 16.76 & $\begin{array}{c}81.36 \\
(54.50)\end{array}$ \\
\hline T. hamatum & 20.00 & $\begin{array}{c}77.77 \\
(51.06)\end{array}$ \\
\hline T. koningii & 27.36 & $\begin{array}{c}69.59 \\
(44.10)\end{array}$ \\
\hline T.Longibrachiatum & 44.90 & $\begin{array}{c}50.18 \\
(30.11)\end{array}$ \\
\hline Gliocladium virens & 42.33 & $\begin{array}{c}53.03 \\
(32.12)\end{array}$ \\
\hline Bacillus subtilis & 40.46 & $\begin{array}{c}55.03 \\
(33.39)\end{array}$ \\
\hline Psudomonas fluorescens & 50.26 & $\begin{array}{c}44.14 \\
(26.20)\end{array}$ \\
\hline Control & 90.00 & $\begin{array}{c}00.00 \\
(00.00)\end{array}$ \\
\hline S.E. \pm & 1.34 & $\mathbf{0 . 8 2}$ \\
\hline C.D. $(P=0.05)$ & 3.98 & 2.44 \\
\hline
\end{tabular}

* Mean of three replications, Dia.: Diameter, \# Figures in parenthesis are Arcs in transformed values
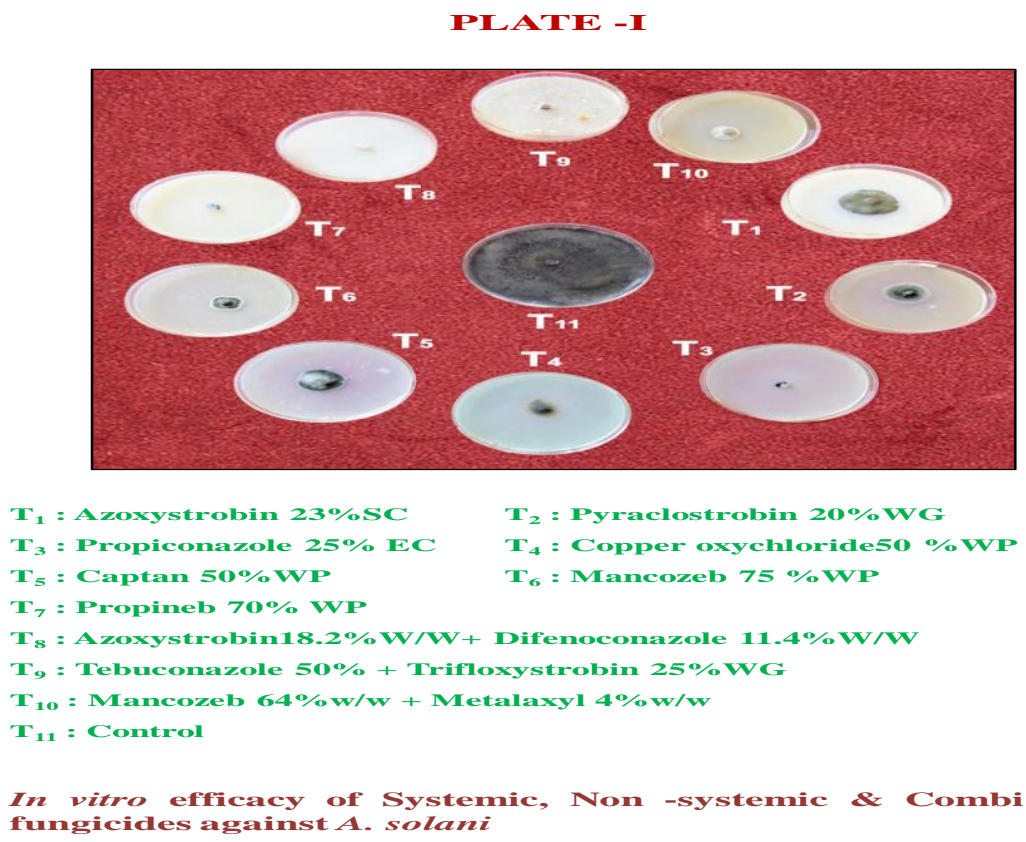


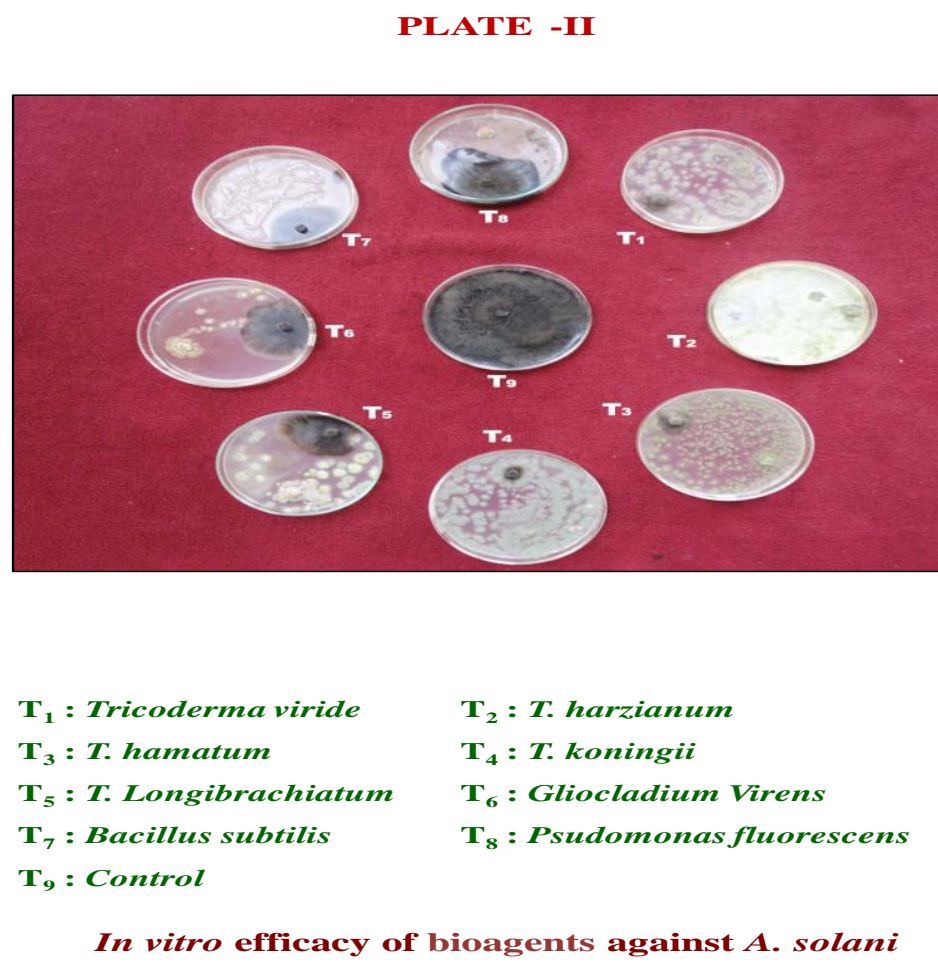

Among bioagents tested, T. harzianum was found most effective with significantly least mycelial growth and highest mycelial growth inhibition of the test pathogen $(16.76 \mathrm{~mm})$ followed by T.hamatum $(20.00 \mathrm{~mm})$ which was at par with each other, and highest mycelial growth inhibition $(81.36 \%)$ of the test pathogen followed by $T$. hamatum (77.77\%). The third best antagonists found $T$. viride with mycelial growth of $22.56 \mathrm{~mm}$ and inhibition of 74.92 per cent. This was followed by $T$. koningii and Bacillus subtilis (27.36 and $40.46 \mathrm{~mm})$ and (69.59 and $55.03 \%$ ) of mycelium growth and its inhibition, respectively. Psudomonas fluorescens was found comparatively less effective with maximum mycelial growth $(50.26 \mathrm{~mm})$ and minimum mycelial growth inhibition (44.14\%).

Results of the present study on antifungal activity of the $T$. viride, $T$. harzianum, $T$. hamatum $T$. koningii and G.virens two bacterial antagonists viz., P. fluorescens and Bacillus subtilis against A.solani are in conformity with those reported earlier by several workers.

Naik et al., (2010 b) evaluated in vitro the bioagents viz., Trichoderma harzianum, $T$. viride, T. koningii and $G$. virens against $A$. chlamydospora, causing leaf blight of okra. They reported all the test bioagents as effective against the test pathogen. However, significantly highest mycelial growth inhibition $(86.29 \%)$ was recorded with $G$. virens, followed by $T$. viride $(85.18 \%), T$. harzianum and T. koningii (84.44\%).

\section{References}

Adhakari P. and D.R Panthee. (2017) Current status of Early blight resistance in early blight: An update Int.J.Mol.sci 18(10).

Basu. P.K. (1974). Measuring early blight, its progress and influence on fruit losses 
in nine tomato cultivars. Canadian Pl. Dis. Surey. 54: 45-51.

Datar, V.V. and Mayee C.D. (1981 a). Assessment of loss in Tomato yield due to early blight. Indian Phytopath. 34: 191-195.

Ellis, J.B. and G.B. Martin (1882). Macrosporium solani. American naturalist. 64(8); 1128-1133.

Gleason, M.L., A.A. MacNab, and I.J. Misaghi, (1993). A stem canker of tomato caused by Alternaria alternata f. sp. lycopersici. Phytopathology 65(4): 880-886.

Gwary, D.M. and H. Nahunnarao, (1998). Epiphytotics of early blight of tomatoes in North-Eastern Nigeria. Crop Prot. 17: 619-629.

Kumar (2017) study on management of Alternaria blight of tomato was carried out in year 2015-2016 under in-vitro condition. International journl of current microbiology and applied sciences ISSN:2319-7706Volume 6Number 5 (2017)pp.2343-2350

Mathur, K. and K.S. Shekhawat (1986). Chemical control of early blight in Kharif Tomato. Indian J. Mycol. Pl. Pathol. 16:235-238.
Naik, U.R., P.A. Fugro, J.J. Kadam, and D.K. Jadhav, $(2010$ b). Exploration of fungicides, bio-agents and botanicals against leaf blight of Okra incited by Alternaria chlamydospora. J. Pl. Dis. Sci. 5(1): 37-40.

Pandey, K.K., P.K Pandey, G. Kallo, and M.K Banerjee. (2003). Resistance to early blight of tomato with respect to various parameters of disease epidemics. J. Gen. Pl. Pathol. 69: 364371.

Rajani, V.V. and D.J. Rakholia. (2012). Management of fruit rot (Alternaria alternata) of chilli through fungicides. (Abst.) J. Mycol. Pl. Pathol. 42 (1): $97-$ 98.

Sherf, A.F., and MacNab, A.A. (1986). Vegetable diseases and their control. John Wiley and Sons, New York, Pp. 634-640.

Walker, J. C. (1951). Diseases of Vegetable Crops. McGraw Hill Book Company, INC, New York, Toranto London: 470475.

Wilson, O. P. (1943). Tomato fruit drop caused by Alternaria solani. Pl. Dis. Reptr. 27: 255.

\section{How to cite this article:}

Pondkule, N. S., V. M. Gholve and Pawar, S. V. 2020. Efficacy of Fungicides and Bioagents against Early Blight of Tomato caused by Alternaria solani. Int.J.Curr.Microbiol.App.Sci. 9(11): 2406-2413. doi: https://doi.org/10.20546/ijcmas.2020.911.289 